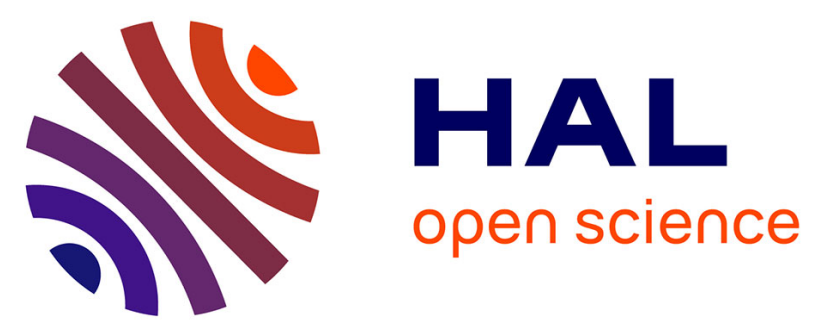

\title{
Development and experimental validation of TPS software to determine the dose outside the radiation beam
}

Igor Bessières, Jean-Marc Bordy, Bénédicte Poumarède

\section{- To cite this version:}

Igor Bessières, Jean-Marc Bordy, Bénédicte Poumarède. Development and experimental validation of TPS software to determine the dose outside the radiation beam. 11th Biennial Conference on Physics and Radiation Technology for Clinical Radiotherapy (ESTRO - 2011), May 2011, London, United Kingdom. Radiotherapy and oncology, Volume 99, Supplement 1, May 2011, Page S176, 99 (supplement 1), S176, poster 436, 2001, 10.1016/S0167-8140(11)70558-8 . cea-02558172

\section{HAL Id: cea-02558172 https://hal-cea.archives-ouvertes.fr/cea-02558172}

Submitted on 30 Apr 2020

HAL is a multi-disciplinary open access archive for the deposit and dissemination of scientific research documents, whether they are published or not. The documents may come from teaching and research institutions in France or abroad, or from public or private research centers.
L'archive ouverte pluridisciplinaire HAL, est destinée au dépôt et à la diffusion de documents scientifiques de niveau recherche, publiés ou non, émanant des établissements d'enseignement et de recherche français ou étrangers, des laboratoires publics ou privés. 


\section{EURADOS}

\section{UNIVERSITÉ}

\author{
BESSIERES Igor 1 \\ BORDY Jean-Marc ${ }^{2}$ \\ POUMAREDE Bénédicte ${ }^{3}$
}

${ }^{1}$ CEA, LIST, DCSI, Laboratoire Modélisation, Simulation et Systèmes, F-91191 Gif-Sur-Yvette, France.

CEA, LIST, LNHB, F-91191 Gif-Sur-Yvette , France.

${ }^{3}$ CEA, LIST, DCSI, F-91191 Gif-Sur-Yvette , France.

igor.bessieres@cea.fr

\title{
MOTIVATION
}

- In the fight against cancers, radiotherapy remains the most powerful and widespread technique.

- Risk of generating second cancers and heart diseases after a first treatment due

to $\mathbf{x}$-rays leakages and scattered radiations that depose out-of-field dose ${ }^{1}$.

- At the moment, TPS optimize the effectiveness of radiation therapy,

based on dose distributions in the target volume, but the dose distributions to distant organs are

not provided.

- It could help the therapist to know the peripheral dose before the treatment in order to

predict and reduce the iatrogenic effects.

Our solution: develop a Monte Carlo tool giving the whole-body dose in a reasonable time.

The peripheral dose is low and consequently difficult to simulate with a small statistical uncertainty.

\section{MATERIAL and METHODS}

Code:

- Tool based on the Penelope ${ }^{2}$ Monte Carlo particle transport code, high accuracy on the dose deposition.

- Calculation of the dose at any part of the patient's body while carrying out treatment planning.

- Implementation of variance reduction techniques to improve the efficiency: better uncertainty for the same simulation time.

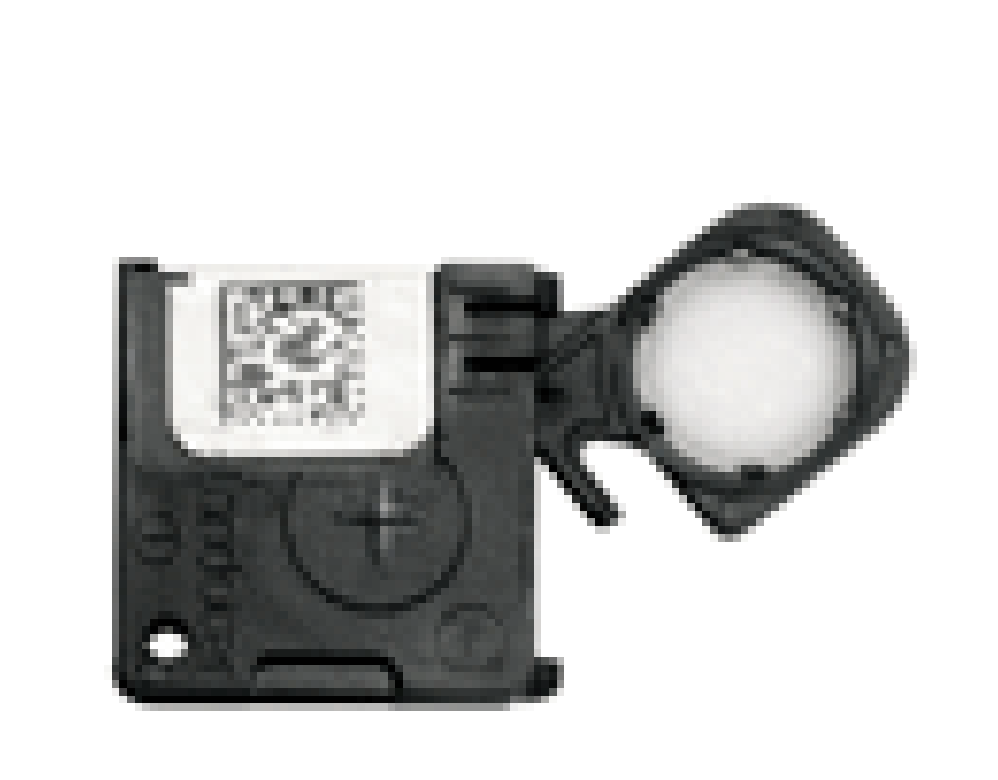

Experimental validation:

On the GE Saturne 43 conventionnal linac on a specific large water tank at 6, 12 and $20 \mathrm{MV}$ with a $10 \times 10 \mathrm{~cm}^{2}$ field at the French Primary Standard Laboratory (done) and an IMRT accelerator on an anthropomorphic phantom (autumn 2011).

Use of the OSL (Optically Stimulated Luminescence) dosimeters: Nanodot from LCIE Landauer.

\section{RESULTS}

Measurements and calculations on the Saturne 43:

Considering that the ionization chamber dose is the reference value,

OSL over-estimate the dose at large distance from the beam centre. It is due to the energy dependence of the dosimeter's response at low energies.

The Penelope code fits better (mean error $3 \%$ ) with the reference than the MCNPX code (mean error $30 \%$ ).

But Penelope is too slow and time consuming for a clinical application

( 26 hours on 108 processors to calculate the dose in the water tank).

Consequently, we need to accelerate the calculation by implementing the Dxtran variance reduction technique.

OSL energy dependence correction:

High over-response below $100 \mathrm{keV}$.

Importance of low energy photons far from the field (Penelope calculations).

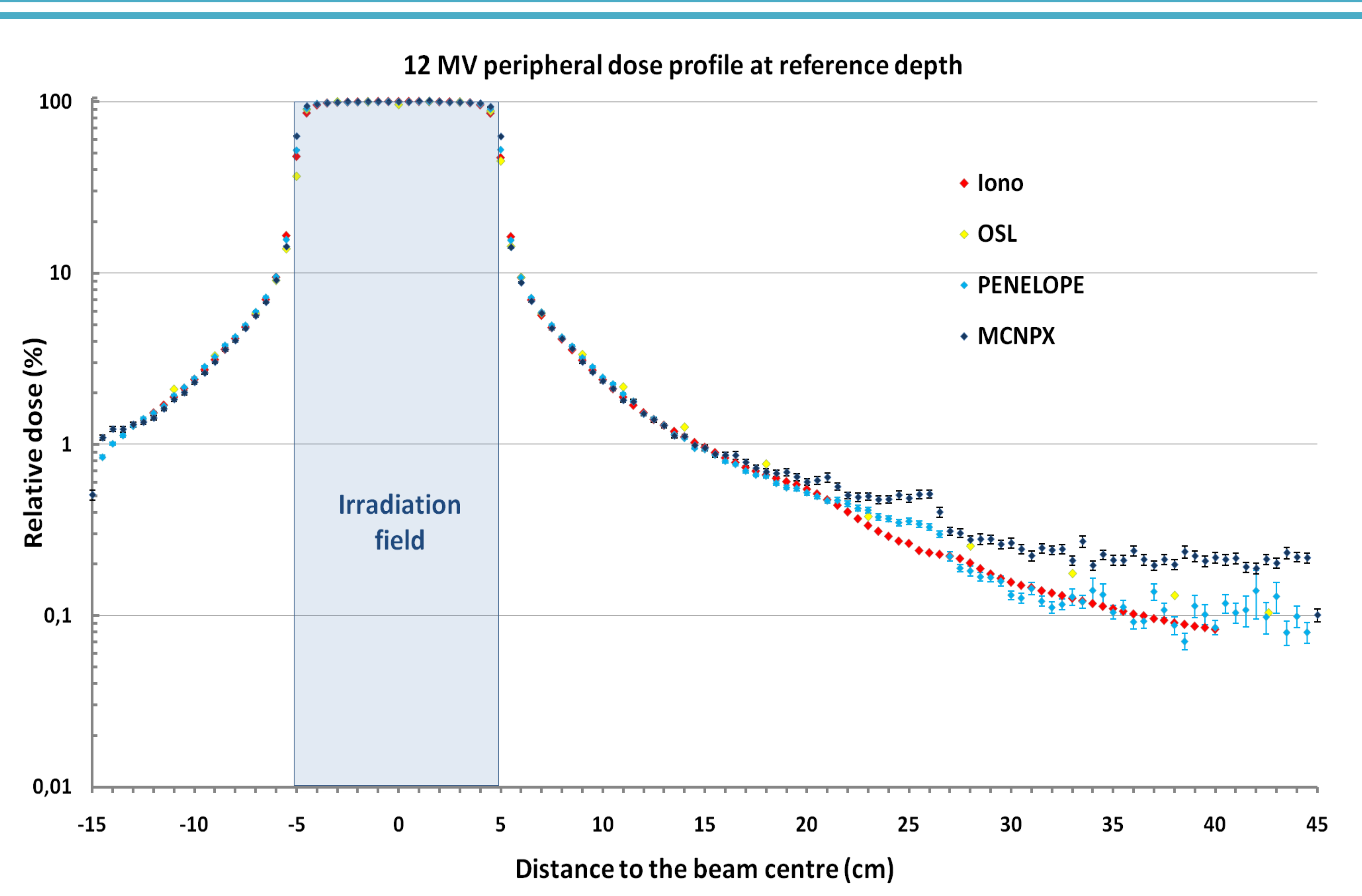
Energy spectra in the water tank

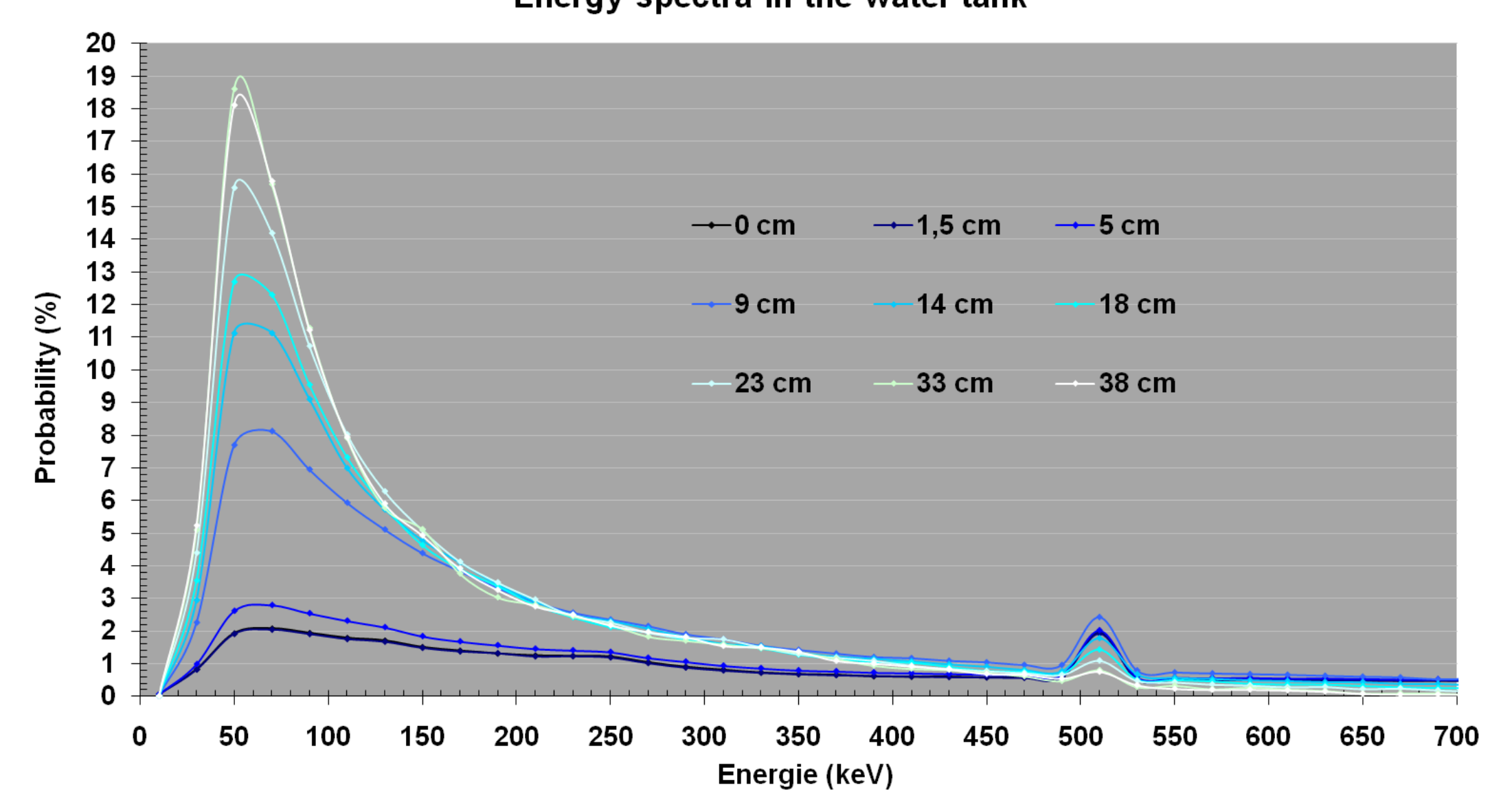

After correcting the energy dependence, the OSL dosimeters will give satisfaying results so that they could be used to validate the code in a real IMRT configuration.

OUTLOOK

- Implementation of the pseudo deterministic transport variance reduction technique in Penelope (in progress).

Subdivision of particle at each interaction: one is forced to reach a region of interest (virtual particle), the other one is the real one that follow its history (non deterministic transport).

- Measurements and validation on an anthropomorphic phantom with OSL detectors.
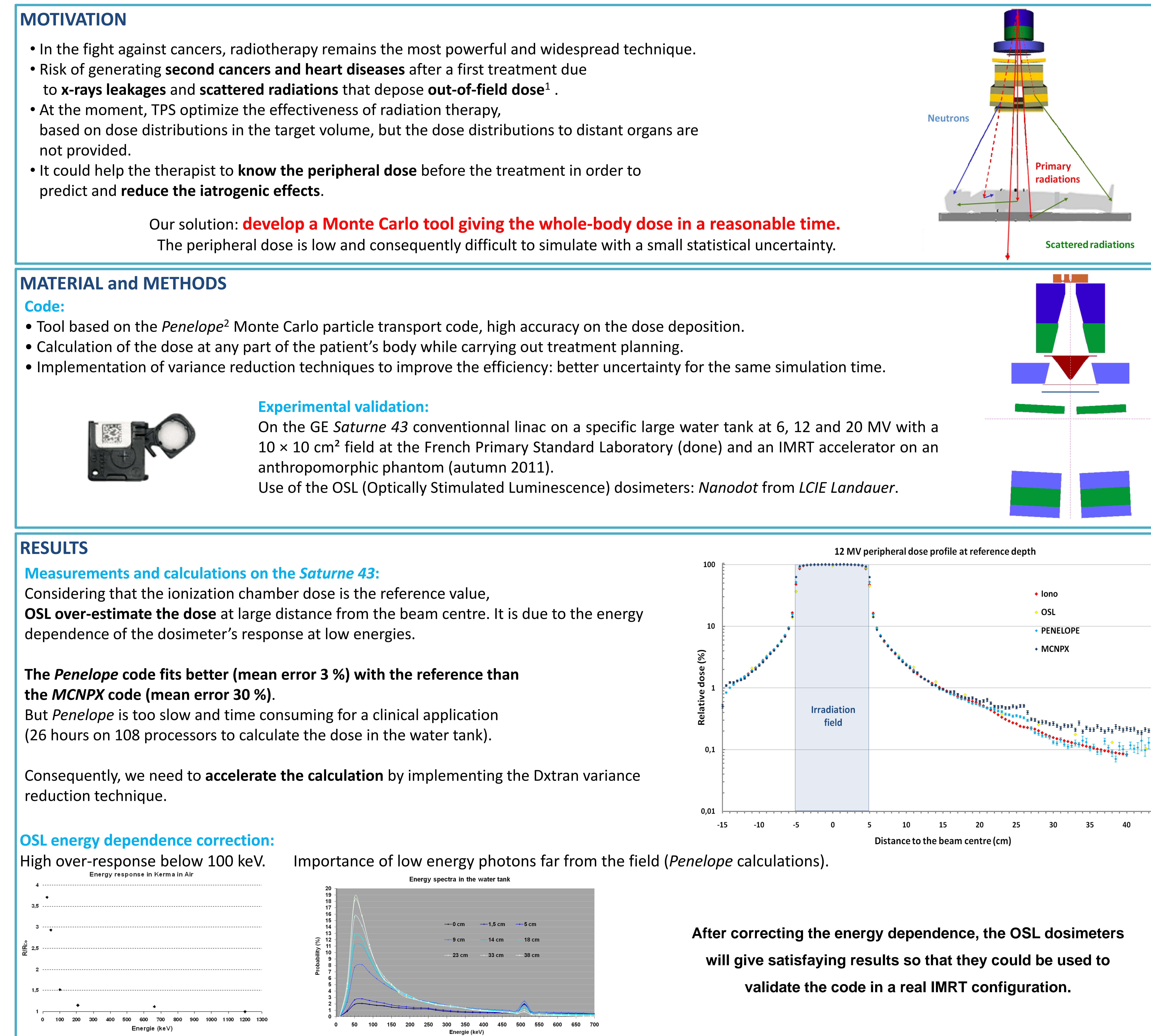

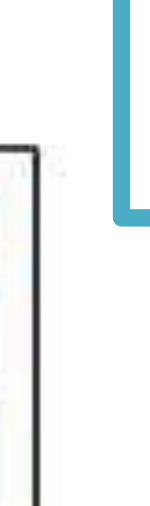

\footnotetext{
REFERENCES

1. Xu G X, Bednarz B \& Paganetti H, 2008, A review of dosimetry studies on external-beam radiation treatment with respect to second cancer induction, Phys. Med. Biol. 53 193-241.
}

2. Salvat F, Fernandez-Varea J-M, Acosta E \& Sempau J, 2001, PENELOPE - A Code System for Monte Carlo Simulation of Electron and Photon Transport 